\title{
Program Intervensi Berbasis Mindfulness untuk Meningkatkan Kesejahteraan Psikologis Caregiver Pasien Kanker Anak
}

\author{
Nur Baiti Astuti ${ }^{1}$ \& Diana Setiyawati \\ Fakultas Psikologi Universitas Gadjah Mada
}

\begin{abstract}
Diagnosis cancer in children can be extremely stressful for caregiver. Caregiver are "hidden patients" who have suffered from physical and psychological problems. However, only few program address the needs caregivers of children with cancer. This research aims to enhance psychological well-being (PWB) using mindfulness based intervention for caregiver. Participants of this study are 6 caregivers of children with cancer in Yayasan Kanker Anak Yogyakarta. The research design is one group pretest-postest design. PWB scale used to measure caregiver's well-being, given before treatment as pretest and after treatments as post test. The descriptive statistic using wilcoxon matched-pairs signed-ranks test showed improvements in psychological well being's caregiver but were not statistically significant $(Z=-1.051, p=0.293(p>0.05)$. However, caregivers had improved in self acceptance after mindfulness program $(Z=-2.207, p=0.016(p<0.05)$.
\end{abstract}

Keywords: caregiver childhood cancer; mindfulness; psychological well-being

Abstrak. Diagnosis kanker pada anak memberikan dampak yang cukup besar bagi keluarga. Keluarga yang berperan sebagai caregiver tanpa disadari merupakan "pasien tersembunyi" yang memiliki banyak permasalahan, baik dari segi kesehatan fisik maupun psikologis. Beban caregiver tersebut mampu menyebabkan kondisi kesejahteraan psikologis yang semakin menurun. Penelitian ini bertujuan untuk meningkatkan kesejahteraan psikologis dengan meningkatkan kemampuan mindfulness pada caregiver. Partisipan dari penelitian ini adalah 6 caregiver pasien kanker anak di Yayasan Kanker Anak Jogja. Metode penelitian yang digunakan adalah the one group pretest-posttest design. Analisis yang digunakan adalah teknik wilcoxon matched-pairs signed-ranks test untuk melihat perbedaan skor mindfulness dan kesejahteraan psikologis partisipan sebelum dan sesudah pemberian perlakuan. Hasil menunjukkan bahwa terjadi peningkatan kesejahteraan psikologis yang tidak signifikan pada caregiver $(\mathrm{Z}=-1.051, \mathrm{p}=0.293(\mathrm{p}>0.05)$. Meski demikian, terjadi peningkatan aspek penerimaan diri pada caregiver setelah program mindfulness berlangsung $(Z=-2.207, p=0.016(p<0.05)$.

Kata kunci: caregiver kanker anak; kesejahteraan psikologis; mindfulness

${ }^{1}$ Korespondensi dapat dilakukan melalui :

nurbaiti.psi@mail.ugm.ac.id

${ }^{2}$ Atau melalui diana_psy@ugm.ac.id 
Penyakit kanker hingga saat ini menjadi masalah kesehatan yang menjadi perhatian dunia. Kanker merupakan penyakit kronis yang tidak menular namun dapat menjadi penyebab kematian. Menurut WHO, jumlah kematian akibat penyakit kanker selalu meningkat setiap tahunnya, dari empat belas juta kasus kanker pada tahun 2012 menjadi dua puluh dua juta dalam dua dekade berikutnya (Kementerian Kesehatan Republik Indonesia, 2015). Berdasarkan statistik pada tahun 2012 yang diperolah dari data Badan Internasional untuk Penelitian Kanker (IARC), diperkirakan 70\% kematian akibat kanker terjadi di negara-negara berkembang. Di Indonesia sendiri, kanker menjadi penyebab kematian nomor dua sebesar $13 \%$ setelah penyakit kardiovaskular (Kemenkes RI, 2015).

Penyakit kanker dapat menyerang siapa saja, baik orang dewasa maupun anak-anak. Data WHO menyebutkan empat persen dari keseluruhan penderita kanker di dunia adalah anak-anak. Sebanyak 160.000 kasus baru kanker pada anak ditemukan setiap tahun dan 90.000 meninggal dunia. Di Indonesia, setiap tahun kurang lebih terdapat 11.000 kasus kanker anak, di mana 650 kasus terjadi di Jakarta (Yayasan Onkologi Anak Indonesia, 2014). Menurut studi yang dilakukan oleh Ali et., al, (2010) selama periode tahun 2000-2009 di Rumah Sakit Sardjito, didapatkan temuan bahwa terdapat 1.124 kasus kanker anak yang terjadi di Yogyakarta.

Diagnosis kanker pada anak pada kenyataannya memberikan dampak yang cukup besar bagi keluarga karena perannya sebagai caregiver. Dampak yang terjadi tidak hanya secara ekonomi, namun juga secara fisik, psikologis, maupun sosial. Hasil penelitian Kohlsdorf dan Junior (2012) menyebutkan bahwa diagnosis kanker pada anak berdampak pada perubahan dalam dinamika keluarga, di antaranya yaitu tantangan dalam biaya finansial, prosedur yang dijalani, distres psikologis, serta penyesuaian terhadap peran dan tanggung jawab yang baru. Hal ini sesuai dengan hasil penelitian Fletcher (2010), yang menyebutkan bahwa keluarga dihadapkan pada pengeluaran yang besar untuk membiayai perawatan anak serta berdampak pada kehilangan pekerjaan. Vrijmoet-Wiersema, et al. (2008) menyebutkan bahwa manifestasi emosi yang dialami pada orang tua atau keluarga terdekat yaitu seperti kondisi ketidakpastian, kecemasan, depresi, dan Post Traumatic Stress Syndrome (PTSS). Caregiver juga dihadapkan pada tantangan komunikasi dengan tenaga profesional medis terkait penyakit dan perawatan yang dijalani anak. Ketidakpastian dan kesulitan terhadap akses informasi terkait penyakit, kondisi fisik anak, prosedur perawatan, dan efek samping pengobatan menjadi faktor yang menambah beban caregiver (Kohlsdorf \& Junior, 2012).

Berdasarkan penjelasan di atas, caregiver dari pasien kanker anak merupakan "pasien tersembunyi" yang memiliki banyak permasalahan, baik dari segi kesehatan fisik maupun dari segi psikologis. Beban dan tanggung jawab yang dialami caregiver tersebut jelas mampu menimbulkan tekanan dan stresor tersendiri. Proses penyembuhan yang harus dijalani oleh pasien kanker anak memang menimbulkan efek stres, bahkan traumatik bagi keluarga (Norberg \& Boman, 2008; Vrijmoet-Wiersma et al., 2008).

Stres yang terus-menerus tanpa adanya tindakan lebih lanjut akan menyebabkan munculnya simtom-simtom 
psikologis seperti perasaan bersalah terusmenerus, ketidakberdayaan, kecemasan, PTSD, hingga depresi (Dolgin et al., 2007; Norberg \& Boman, 2008; VrijmoetWiersmaet et al., 2008). Oleh karenanya, caregiver pasien kanker anak lebih memiliki risiko untuk mengalami kecemasan dan depresi dibanding keluarga lain yang tidak mempunyai riwayat anak sakit (Okado, Long, \& Phipps, 2014).

Banyak penelitian menunjukkan adanya penurunan kondisi kesehatan dan kualitas hidup, bahkan meningkatnya kematian dan morbiditas pada keluarga caregiver. Lebih lanjut, penelitian juga menyebutkan bahwa beban caregiver berhubungan dengan kondisi kesejahteraan diri yang semakin menurun (Li, Yuan, \& Zhang, 2016). Dampak peran sebagai caregiver adalah bahwa individu akan sangat mungkin mengabaikan kesehatan dan kondisi kesejahteraan psikologisnya. Hal ini dikarenakan energi mereka sudah habis dalam proses melayani kebutuhan anak yang sakit. Padahal kondisi kesehatan caregiver sangat berpengaruh terhadap kondisi kesehatan care-recipient.

Caregiver yang memiliki kesejahteraan psikologis yang tinggi diharapkan memiliki konsentrasi yang penuh dan dedikasi tinggi yang berfungsi adekuat dalam mendukung peran caregiver mereka dalam melayani kebutuhan anak. Oleh karena itu, sangat penting dibutuhkan pelayanan kesehatan untuk caregiver, terutama untuk meningkatkan kesejahteraan psikologis (psychological well being).

Brown dan Ryan (2003) menemukan bahwa mindfulness berkaitan dengan indikator kognitif dan afektif dari kesehatan mental, termasuk penurunan level gangguan emosi (seperti depresi, cemas, dan stres) dan peningkatan level well-being (seperti vitalitas, afek positif, dan kepuasan hidup). Jika dihubungkan dengan aktivitas otak, mindfulness mampu meningkatkan kemampuan individu untuk mengelola emosi. Partisipan yang diberikan keterampilan mindfulness menunjukkan penyebaran aktivasi prefrontal korteks dan mengurangi respon amygdala selama proses diberikan. Temuan tersebut menunjukkan bahwa mindfulness mampu membuat individu merasakan dan menyadari emosi secara selektif, yaitu memberi jarak atau detachment terhadap emosi negatif (Creswell, Way, Eisenberger, \& Lieberman, 2007). Mindfulness juga terbukti mampu meningkatkan kapasitas neuroplasticity, yaitu kemampuan membentuk konfigurasi baru neuron di otak. Perubahan yang terjadi yaitu penebalan di bagian region otak yang berkaitan dengan perhatian, fokus, proses sensori, sensivitas terhadap stimulus internal dalam tubuh (Davis \& Hayes, 2011).

Hölzel, et al., (2011) menyebutkan bahwa kecenderungan untuk merespon masalah secara berkesadaran (mindful) dapat menurunkan aktivitas amigdala, sehingga ketika dihadapkan pada suatu permasalahan, respon dari emosi negatif menjadi tidak berlebihan. Menurut Asuero, et al. (2014) mindfulness juga dapat menurunkan burnout dan meningkatkan kesejahteraan psikologis pada petugas medis. Hanley, Warner, dan Garland, (2015) menemukan jika dibandingkan antara kesejahteraan psikologis (PWB) dengan kesejahteraan partisipantif (SWB), mindfulness berasosiasi lebih dekat dengan PWB.

Mindfulness membantu seseorang dalam mengatasi berbagai permasalahan dengan pikiran yang lebih terbuka karena mereka memiliki kontrol yang penuh terhadap perilaku dan emosinya, sehingga dapat mencegah afek negatif yang secara 
otomatis muncul ketika dihadapkan pada stressor (Compton \& Hoffman, 2013). Praktik mindfulness memberikan kemungkinan individu menjadi lebih sadar (aware), secara perlahan mengurangi respon otomatis dalam menghadapi sesuatu, memberikan perhatian terhadap apa yang sedang terjadi pada tubuh dan apa yang diinginkan oleh tubuh, dan memberikan waktu jeda sebelum respon otomatis keluar. Pada akhirnya mindfulness mampu membantu individu untuk memilih reaksi yang tepat, dan dalam perkara tertentu, membantu memilih untuk menjadi tidak reaktif, terlebih ketika berhubungan dengan anak (Bogels \& Restifo, 2014). Mindfulness menjadi hal yang krusial bagi caregiver pasien kanker anak untuk meningkatkan well being karena dihadapkan terus menerus pada situasi emosional dan penuh stresor, sehingga mengharuskan dirinya untuk selalu siaga dan tidak terganggu dengan emosi atau pengalaman negatif ketika sedang berhadapan dengan anak.

Penelitian menggunakan intervensi berdasarkan konsep Mindfulness Based Cognitive Therapy (MBCT) oleh Segal, William, dan Teasdale (2002) dengan memasukkan konsep pola asuh berkesadaran (mindful parenting) oleh Bogels dan Restifo (2014). Intervensi berbasis mindfulness pada caregiver kanker anak ini diharapkan mampu bermanfaat untuk meningkatkan kesehatan mental caregiver. Hipotesis yang diajukan dalam penelitian ini adalah program berbasis mindfulness dapat meningkatkan kesejahteraan psikologis (PWB) caregiver pasien kanker anak.

\section{Metode}

Partisipan pada penelitian ini adalah enam orang caregiver pasien kanker anak. Penelitian diadakan di Yayasan Kasih Anak Kanker Jogja (YKAKJ). Penelitian ini menggunakan desain penelitian "the one group pretest-posttest design" (Shadish, Cook, \& Campbell, 2002). Kriteria inklusi partisipan yang diterapkan dalam penelitian ini adalah (1) Partisipan merupakan caregiver pasien kanker anak di YKAKJ; (2) Partisipan mampu melakukan mobilisasi secara memadai untuk bergabung dalam kelompok; (3) Partisipan mampu berbahasa Indonesia dengan baik dan benar secara lisan dan tertulis; (5) Partisipan bersedia berpartisipasi dalam proses penelitian dan memenuhi hak serta kewajiban sebagai partisipan penelitian yang dibuktikan dengan kesediaannya untuk mengisi informed consent penelitian.

Instrumen penelitian terdiri dari (1) Lembar informed consent; (2) Skala mindfulness menggunakan Kentucky Inventory Mindfulness Skill (KIMS) oleh Baer, Smith, dan Allen, (2004). Peneliti menggunakan metode forward translationback translation untuk mengadaptasi skala tersebut ke Bahasa Indonesia; (3) Skala kesejahteraan psikologis menggunakan skala yang dimodifikasi berdasarkan teori dari Ryff (1989); (4) Modul Intervensi berbasis Mindfulness.

\section{Validasi alat ukur}

Uji validitas skala mindfulness (KIMS) menggunakan validitas isi (content validity). Hasil uji validitas yang dilakukan oleh lima orang rater menunjukkan nilai Aiken's V yang berkisar antara 0.65-0.95, dengan nilai rata-rata 0.846 . Kemudian hasil uji coba terhadap 50 orang dengan rentang usia 22-56 tahun menunjukkan nilai koefisien reliabilitas Alpha Cronbach sebesar 0.815. Sedangkan untuk Skala Kesejahteraan Psikologis, uji validitas isi menunjukkan nilai Aiken's V yang berkisar antara 0.75-0.95, dengan nilai rata-rata 0.887 . Kemudian hasil uji coba menunjukkan nilai koefisien reliabilitas Alpha Cronbach sebesar 0.888. 
Tabel 1.

Deskripsi partisipan penelitian

\begin{tabular}{cllll}
\hline Nama (Inisial) & Usia (th) & Pendidikan & Pekerjaan & Lama anak sakit \\
\hline MR & 53 & SLTP & Swasta & Minggu ke 27 \\
MH & 33 & SD & Buruh & Minggu ke 75 \\
MM & 25 & SD & Buruh & Minggu ke 25 \\
MD & 43 & SMA & IRT & Minggu ke 14 \\
MA & 27 & SMK & Swasta & Minggu ke 27 \\
ME & 38 & SLTP & IRT & Minggu ke 10 \\
\hline
\end{tabular}

Validasi Modul

Proses pertama yang dilakukan dalam validasi modul adalah penilaian (professional judgement) oleh tiga orang ahli, yaitu satu orang dosen sekaligus praktisi psikolog, dan dua orang praktisi psikolog dengan latar belakang mindfulness. Hasil menunjukkan nilai Aiken's $V$ yang berkisar antara dari 0.75-1 dengan rerata 0.91 .

Proses pengujian reliabilitas kesepakatan antar rater dalam melakukan penilaian terhadap modul program menggunakan metode intra-class correlation (ICC). Hasil analisis ICC menunjukkan bahwa Modul Mindfulness memiliki rerata kesepakatan antar rater sebesar 0.923. Hal ini mengindikasikan bahwa kesepakatan antar rater telah memuaskan.

Proses uji coba modul dilakukan dengan menerapkan proses intervensi yang sesuai dengan modul. Uji coba modul dilakukan pada tanggal di Desa Rejodani, Sleman selama empat kali pertemuan. Partisipan uji coba adalah sembilan ibu, dengan rentang usia antara 33-51 tahun. Analisis hasil skor mindfulness pada partisipan dilakukan dengan uji wilcoxon sign-rank test didapatkan perbedaan signifikan antara skor pretest dan postest pada skor mindfulness dengan $Z=-2.524, p=0.012(p<0.05)$. Hal ini berarti modul mindfulness telah teruji untuk meningkatkan mindfulness partisipan.

\section{Pelaksanaan}

Program Mindfulness dilakukan di ruangan belajar di Yayasan Kasih Anak Kanker Jogja. Sebelum memulai pelaksanaan, partisipan telah menandatangani informed consent terlebih dahulu. Proses pelaksanaan intervensi dilakukan selama empat kali pertemuan dalam kurun waktu tiga minggu. Jumlah peserta yang pada awalnya berjumlah tujuh orang, hingga akhir program menjadi 6 orang, Satu orang partisipan dinyatakan gugur karena tidak dapat hadir di pertemuan terakhir.

\section{Hasil}

Deskripsi partisipan

Partisipan penelitian terdiri dari enam orang. Partisipan merupakan caregiver pasien kanker anak di YKAKJ yang dapat dilihat pada tabel 2 . 
Pengukuran manipulation check

Perubahan skor mindfulness partisipan sebelum dan sesudah dilakukan intervensi dapat dilihat pada tabel berikut.

Tabel 2.

\begin{tabular}{|c|c|c|c|}
\hline \multirow[t]{2}{*}{ No } & \multirow[t]{2}{*}{ Partisipan } & \multicolumn{2}{|c|}{ Skor mindfulness } \\
\hline & & Pretest & Postest \\
\hline 1. & MR & 82 & 85 \\
\hline 2. & $\mathrm{MH}$ & 75 & 80 \\
\hline 3. & MM & 91 & 92 \\
\hline 4. & MD & 73 & 82 \\
\hline 5. & MA & 76 & 91 \\
\hline 6. & ME & 74 & 79 \\
\hline & Mean & 78.5 & 84.8 \\
\hline
\end{tabular}

Berdasarkan Tabel. 3 dapat diketahui bahwa terdapat perubahan skor setiap partisipan saat pretest maupun postest. Selanjutnya untuk melihat apakah perubahan ini secara statistik signifikan, peneliti melakukan uji wilcoxon signed-rank test. Hasil menunjukkan peningkatan skor yang signifikan pada partisipan setelah mengikuti program mindfulness, dengan nilai $Z=-2.207, p=0.027(p<0.05)$. Hal ini berarti terdapat peningkatan mindfulness pada partisipan setelah mengikuti program mindfulness.

Selain diukur menggunakan skala, cek manipulasi dilakukan menggunakan pengukuran terhadap indikator keberhasilan tujuan program intervensi. Hal ini dinilai berdasarkan hasil observasi observer mengenai indikator ketercapaian tujuan program intervensi. Hasil observasi indikator keberhasilan program dianalisis menggunakan metode Cohen's Kappa untuk melihat kesepakatan antar 2 rater. Hasil reliabilitas antar rater yaitu $\mathrm{K}=0.843$, dengan asumsi eror 0.153. Hal ini menunjukkan bahwa tingkat reliabilitas antar rater masuk dalam kategori baik (almost perfect agreement) (Landis \& Koch, 1977), dengan standar eror yang kecil sehingga semakin reliable hasil pengukuran yang dihasilkan.

Setelah mengetahui nilai kesepakatan antar rater, peneliti menganalisis keseluruhan penilaian observer dengan menggunakan rumus persentase keberhasilan untuk mengetahui sejauh mana proses program yang dilakukan telah berjalan sesuai dengan tujuan. Hasil analisis menunjukkan bahwa proses terapi telah mencapai $91.02 \%$ dari indikator keberhasilan program sehingga dapat disimpulkan bahwa intervensi atau manipulasi yang diberikan telah sesuai dengan rancangan penelitian.

\section{Uji hipotesis}

Perubahan skor kesejahteraan diri pada partisipan sebelum dan sesudah dilakukan intervensi dapat dilihat pada Tabel 3.

Tabel 3.

Skor kesejahteraan psikologis partisipan penelitian

\begin{tabular}{ccc}
\hline Partisipan & Pretest & Postest \\
\hline MR & 99 & 104 \\
MH & 100 & 89 \\
MM & 113 & 110 \\
MD & 94 & 115 \\
MA & 112 & 124 \\
ME & 108 & 111 \\
\hline Mean & 104.33 & 108.83 \\
\hline
\end{tabular}

Berdasarkan Tabel. 3 dapat diketahui bahwa terdapat perubahan skor setiap partisipandari pretest ke postest. Selanjutnya untuk melihat apakah perubahan ini secara statistik signifikan, 
peneliti melakukan uji hipotesis. Peneliti menggunakan wilcoxon signed-rank test untuk menguji hipotesis yaitu melihat apakah ada perbedaan skor pada pengukuran pretest dan postest secara statistic. Wilcoxon signed-rank test juga digunakan ketika syarat asumsi parametrik tidak terpenuhi yaitu tidak terpenuhinya uji normalitas, uji homogenitas, dan jumlah sampel kecil (Sani \& Todman, 2006). Hasil analisis menunjukkan bahwa tidak terdapat perbedaan yang signifikan antara skor pretest dan postest pada kesejahteraan psikologis partisipan $(Z=-1.051 ; p=0.172$; $(p>0.05))$.

\section{Uji analisis tambahan}

Peneliti melakukan uji analisis tambahan untuk mengetahui pengaruh intervensi berbasis mindfulness terhadap setiap aspek dari kesejahteraan psikologis. Kesejahteraan psikologis memiliki enam aspek, yaitu otonomi, hubungan positif, pemahaman lingkungan, perkembangan pribadi, tujuan hidup, dan penerimaan diri.

Tabel 4.

Hasil analisis skor aspek kesejahteraan psikologis

\begin{tabular}{llllll}
\hline No & Aspek & $\begin{array}{l}\text { ESkor } \\
\text { pretest }\end{array}$ & $\begin{array}{l}\text { ESkor } \\
\text { postest }\end{array}$ & Z & Sign. \\
\hline 1 & Otonomi & 105 & 103 & 0.00 & 0.625 \\
2 & Hubungan Positif & 107 & 100 & -948 & 0.219 \\
3 & $\begin{array}{l}\text { Pemahaman } \\
\text { lingkungan }\end{array}$ & 101 & 104 & -1.134 & 0.250 \\
4 & $\begin{array}{l}\text { Perkembangan } \\
\text { pribadi }\end{array}$ & 85 & 90 & -962 & 0.250 \\
& & & & \\
5 & Tujuan hidup & 115 & 113 & -406 & 0.375 \\
6 & Penerimaan diri & 113 & 143 & -2.207 & $0.016^{*}$ \\
\hline
\end{tabular}

${ }^{*} \mathrm{p}<0.05=$ signifikan

Berdasarkan Tabel 4 dapat disimpulkan bahwa dari keenam aspek kesejahteraan psikologis, hanya aspek penerimaan diri yang mengalami peningkatan secara signifikan $(Z=-2.207$; $p=0.016)$, sedangkan aspek yang lain tidak mengalami peningkatan signifikan. Hal ini berarti terdapat peningkatan penerimaan diri yang signifikan pasca partisipan setelah mengikuti intervensi.

\section{Diskusi}

Hipotesis yang diajukan dalam penelitian ini adalah program mindfulness dapat meningkatkan kesejahteraan psikologis pada caregiver pasien kanker anak. Terdapat peningkatan rerata skor kesejahteraan psikologis setelah mengikuti program mindfulness namun berdasarkan hasil analisis uji statistik menunjukkan peningkatan kesejahteraan psikologis yang tidak signifikan, yang ditunjukkan dengan nilai $Z=-1.051, p=0.293(p>0.05)$. Berdasarkan hasil uji statistik disimpulkan bahwa program mindfulness tidak teruji meningkatkan kesejahteraan psikologis caregiver kanker anak.

Hasil yang tidak signifikan dari uji hipotesis diperkirakan karena idealnya intervensi berbasis mindfulness dilaksanakan dalam 8 minggu dengan total waktu 
26 jam. Meski demikian, telah dilaporkan bahwa waktu yang dibutuhkan untuk komitmen mengikuti proses tersebut yang sering menjadi alasan berkurangnya jumlah partisipan (Carmody \& Baer, 2009). Namun di sisi lain, lama program untuk partisipan caregiver kanker sendiri dapat dimodifikasi menjadi lebih sedikit yaitu selama 6 minggu dengan 3 minggu pertemuan tatap muka in class dan 3 minggu latihan di rumah (Lengacher, et al., 2012). Lebih lanjut lagi, hasil penelitian baru-baru ini menyebutkan bahwa hanya dengan sesi single-brief mindfulness pun dapat menghasilkan efek positif secara langsung terhadap regulasi emosi, kecemasan, (Keng, Smoski, \& Robins, 2011) dan juga trait mindfulness itu sendiri (Howarth et al., 2016).

Hasil yang tidak signifikan terhadap efek positif yang dihasilkan oleh program mindfulness untuk caregiver pasien kanker sejalan dengan penelitian Lengacher, et al., (2012). Hasil penelitian Lengacher menyatakan bahwa caregiver mengalami perubahan kenaikan status psikologis dan kualitas hidup namun kenaikannya tidak signifikan. Dari penelitian tersebut, hasil yang tidak signifikan diperkirakan karena partisipan banyak dropout serta komitmen yang kurang karena terjadi konflik terhadap waktu terkait jadwal kemoterapi dan jadwal kontrol dokter yang berbedabeda, serta kurangnya kontrol dari karakteristik dari caregiver, seperti kondisi fisik, stresor harian, jenis penyakit anak, dan demografis dari partisipan. Hal ini sejalan dengan apa yang terjadi saat proses pelaksanaan intervensi dalam penelitian ini bahwa komitmen yang kurang terhadap waktu intervensi dan kurangnya kontrol dari segi karakteristik partisipan.
Hasil temuan dari uji analisis tambahan dari penelitian ini adalah bahwa partisipan mengalami peningkatan aspek penerimaan diri setelah mendapatkan intervensi berbasis mindfulness, dengan nilai $Z=-2.207 ; p=0.016(p<0.05)$. Temuan ini didukung oleh Hoppes, Bryce, Hellman, \& Finlay, (2012) yang menyebutkan bahwa dosis rendah dari pelatihan mindfulness, yaitu 3 minggu pelatihan secara tatap muka dapat meningkatkan penerimaan diri dari caregiver kanker. Penelitian lain dari Carson dan Langer, (2006) juga menyebutkan bahwa intervensi berbasis mindfulness mampu memengaruhi penerimaan diri. Kemudian, Brown dan Ryan (2003) menambahkan bahwa sikap tanpa penilaian dalam minduflness berkaitan dengan penerimaan individu terhadap pengalaman sehingga membuat individu mampu menghadapi pikiran atau perasaan yang tidak nyaman. Hal ini menunjukkan bahwa mindfulness bermanfaat bagi partisipan untuk menerima kondisi sekarang yang sedang dijalani, sekaligus menerima perannya sebagai caregiver anak sakit kanker. Partisipan juga mampu menerima keberhasilan maupun kegagalannya secara personal.

Hasil pengamatan rerata skala ukur diri menunjukkan semua partisipan memahami penjelasan hampir di setiap sesi, dapat mengikuti instruksi, dan merasakan manfaat setiap sesi. Teknik mindfulness yang paling sering dipraktikkan oleh partisipan adalah nafas berkesadaran, memberi jeda, dan praktik kebersyukuran. Praktik nafas berkesadaran adalah teknik yang paling mudah dipraktikkan partisipan dan manfaatnya dapat langsung dirasakan partisipan seperti menenangkan pikiran dan badan 
menjadi lebih nyaman. Nafas berkesadaran seperti praktik 3-minute breathing akan membuat nafas mejadi lebih stabil, yang secara bertahap akan membuat detak jantung dan tekanan darah menjadi lebih teratur (Stahl \& Goldstein, 2010).

Saat sesi memberi jeda, partisipan dapat merasa lebih santai dan perasaan senang serta lebih menyadari pola interaksi dengan anak. Praktik memberi jeda ini membuat partisipan menjadi lebih sadar bagaimana cara merespon situasi stres secara lebih baik. Partisipan yang menyadari bahwa ia mudah marah karena terlampau khawatir dengan kondisi anak, dengan memberi jeda ini membantunya lebih tenang saat menghadapi masalah dengan anak. Menurut pandangan neuropsikolog, praktik memberi jeda ini membantu kemampuan otak untuk menghambat respon impulsif, yaitu dengan memberikan waktu lebih banyak untuk mengamati situasi (observe) dan kemudian merencanakan respon (Bogels \& Restifo, 2014). Hal inilah yang membantu individu menjadi tidak mudah reaktif saat menghadapi situasi stres.

Sesi kebersyukuran, memberikan manfaat dengan memunculkan rasa bersyukur, rasa lebih menerima dan ikhlas, serta lebih mencintai dan bangga dengan diri sendiri. Partisipan mampu melihat sisi positif dari dirinya masingmasing dan sisi positif dari kondisi yang sekarang di alami. Partisipan merasa berada dalam kondisi yang sulit, namun merasa bisa menyikapi setiap kesulitan dengan lebih baik.

Semua partisipan merupakan keluarga yang berperan sebagai caregiver dari pasien kanker anak. Beban yang dialami sangatlah berat termasuk beban psikologis maupun finansial. Stres yang terus-menerus dialami caregiver kanker anak akan menyebabkan munculnya simtom-simtom psikologis seperti perasaan bersalah terus-menerus, ketidakberdayaan, kecemasan, trauma, hingga depresi (Dolgin et al., 2007; Norberg \& Boman, 2008; Vrijmoet-Wiersma et al., 2008). Keenam pendamping mengalami berbagai kesulitan ketika menghadapi kondisi kesehatan anak yang tidak stabil dan mudah berubah. Beban psikologis mereka sangat berat hingga menimbulkan stres yang berkepanjangan bahkan hingga memungkinkan depresi.

Stres yang dialami oleh orang tua sebagai caregiver juga dipengaruhi oleh fase penyakit yang sedang dialami anak. Orang tua dalam fase diagnosis (kurang lebih 2 bulan setelah diagnosis) lebih membutuhkan dukungan dari banyak aspek yaitu secara psikologis, medis, finansial, dan kebutuhan informasi. Caregiver masa awal ini dilaporkan memiliki kerentanan yang lebih besar mengalami distres psikologis yang lebih akut seperti kemarahan, kecemasan, ketakutan, bahkan hingga depresi (Northouse et al., 2012). Terdapat beberapa partisipan yang berada pada masa diagnosis awal sehingga masih terlihat penolakan terhadap sakit yang dialami anaknya. Hal inilah yang turut memengaruhi proses intervensi. Northouse, et al. (2012) menyebutkan bahwa kondisi emosi yang berat seperti stres hingga depresi pada caregiver saat menjalani pelatihan berpengaruh terhadap keefektifan pelatihan. Distress psikologis yang semakin memburuk akan semakin menunjukkan kesejahteraan psikologis yang diperkirakan akan menurun (Ryff, 1989). 
Faktor lain yang memengaruhi hasil pelatihan program mindfulness pada penelitian antara lain karakteristik partisipan, seperti keterbukaan dan konsistensi berlatih mindfulness informal ketika di rumah. Beberapa partisipan yang memiliki kondisi emosi masih berat menunjukkan tingkat keaktifan untuk berbagi cerita yang lebih rendah. Padahal menurut pandangan eudaimonic menegaskan bahwa keterbukaan dan pengendalian emosi merupakan hal penting bagi kesejahteraan psikologis (Ryan \& Deci, 2001). Kemudian tingkat kepatuhan partisipan dalam mengikuti pelatihan dan mempraktikkan mindfulness di kehidupan sehari-hari selama program dan setelah program juga turut memengaruhi hasil pelatihan. Haines, Spadaro, Choi, Hoffman, \& Blazeck (2014) menyebutkan bahwa caregiver dari pasien dengan sakit kronis memiliki tingkat kepatuhan yang rendah terhadap pelatihan dalam setting kelompok dibanding caregiver yang berpartisipasi dalam pelatihan mindfulness secara individual (in-person class).

Faktor lain yang turut berpengaruh adalah tingkat pendidikan, kedua partisipan dengan skor kesejahteraan psikologisnya yang justru turun ternyata mempunyai kesamaan tingkat pendidikan Sekolah Dasar. Hal ini disebabkan pula oleh kenaikan skor mindfulness keduanya yang tidak terlalu tinggi dibanding partisipan yang lain. Keyes et al. (2002) melaporkan bahwa tingkat pendidikan yang lebih tinggi memprediksi tingginya skor total dari kesejahteraan psikologis, begitu juga sebaliknya semakin rendah tingkat pendidikan akan memengaruhi efikasi diri yang akan berefek terhadap rendahnya kesejahteraan psikologis.
Berdasarkan penelitian Chang, Huang, dan Lin, (2015) menyebutkan bahwa hubungan antara mindfulness dengan kesejahteraan psikologis dimediasi oleh tiga kebutuhan psikologis dasar yaitu otonomi, hubungan dengan lingkungan, dan kompetensi. Terpenuhinya ketiga kebutuhan dasar tersebut maka dapat diambil kesimpulan bahwa telah mencapai kondisi optimal kesejahteraan psikologis seseorang. Sebaliknya, tidak terpenuhinya kebutuhan dasar tersebut maka individu lebih sulit untuk mencapai kondisi optimal. Individu yang berperan sebagai caregiver, maka ia akan lebih sulit untuk mencapai kondisi yang optimal.

Ancaman validitas eksperimen terhadap penarikan kesimpulan dalam penelitian ini yaitu ancaman terhadap validitas kesimpulan statistik. Validitas kesimpulan statistik adalah jumlah partisipan yang kecil dan faktor extraneous pada setting eksperimen (Shadish, Cook, \& Campbell, 2002). Ellis (2010) mengatakan bahwa semakin kecil jumlah sampel maka semakin kecil kemungkinan terjadi hasil yang signifikan secara statistik. Faktor setting eksperimen yaitu kondisi ruangan ketika berlatih mengalami beberapa gangguan, hal ini disebabkan anak dari partisipan yang beberapa kali masuk ke ruangan sehingga cukup mengganggu konsentrasi.

Ancaman terhadap validitas internal pada penelitian ini berupa selection dan history (Shadish, Cook, Campbell, 2002). Faktor seleksi berupa pemilihan partisipan dari tingkat pendidikan dan juga fase pengobatan anak. Tingkat pendidikan memengaruhi pemahaman partisipan. Sedangkan materi yang diberikan fase pengobatan anak memengaruhi tingkat emosi dan tekanan psikologis yang 
dialami oleh partisipan. Faktor sejarah (history) berupa peristiwa yang dialami partisipan dalam kehidupan pribadi juga turut berpengaruh selama masa penelitian. Partisipan $\mathrm{MH}$ dan $\mathrm{MM}$ mengalami penurunan skor kesejahteraan psikologis pada postest berhubungan dengan kondisi partisipan menurun karena anak baru saja masuk ke rumah sakit.

Beberapa keterbatasan pada proses penelitian ini adalah: 1) Rekruitmen partisipan ke dalam grup sebaiknya dengan melihat tingkat motivasi dan komitmen yang tinggi untuk mengikuti program. 2) Asesmen yang dilakukan kurang mendalam. Hal tersebut mengakibatkan peneliti tidak mempertimbangkan karakteristik partisipan, seperti tingkat pendidikan, lama penyakit yang diderita anak (fase pengobatan), dan karakteristik pribadi yang tepat diberikan intervensi secara kelompok atau secara individual. 3) Tidak adanya kontrol terhadap stresor harian atau perubahan kondisi yang dialami anak.

\section{Kesimpulan}

Hasil analisis data dan diskusi menunjukkan Program Mindfulness tidak teruji untuk meningkatkan kesejahteraan psikologis caregiver kanker anak. Pengamatan terhadap cek manipulasi menunjukkan bahwa Program Mindfulness mampu meningkatkan mindfulness caregiver pasien kanker anak. Temuan dalam penelitian ini adalah bahwa program mindfulness mampu meningkatkan aspek penerimaan diri dari partisipan. Praktik mindfulness memfasilitasi individu lebih menyadari proses dalam diri individu dan mengamati (pikiran, perasaan, dan reaksi tubuh). Ancaman terhadap validitas kesimpulan statistik berupa faktor extraneous pada setting eksperimen. Ancaman terhadap validitas internal eksperimen berupa seleksi partisipan dan peristiwa dalam kehidupan partisipan selama penelitian.

\section{Saran}

Partisipan diharapkan tetap mempraktikkan mindfulness secara formal maupun informal. Hal ini dikarenakan berdasar laporan partisipan bahwa partisipan mendapatkan manfaat seperti perasaan lebih tenang dan lebih mampu menerima kondisi dan dirinya setelah mempraktikkan mindfulness.

Pada saat pemilihan partisipan dapat dilakukan asesmen yang lebih mendalam mengenai karakteristik demografis partisipan, termasuk tingkat pendidikan dan lama fase pengobatan yang telah dijalani anak. Melihat tingkat adherence yang cukup rendah dalam menjalankan program mindfulness bagi caregiver kanker anak secara kelompok, hal ini mengindikasikan bahwa sesi secara individu (in-person class) akan lebih efektif bagi caregiver. Perlu ditambahkan pula sesi psikoedukasi yang lebih mendalam sebelum memulai praktik mindfulness di setiap sesi. Perlu dipertimbangkan kembali untuk menggunakan tugas rumah yang mengharuskan menuliskan pengalamannya di lembar kerja.

Program mindfulness dapat menjadi bagian program pendampingan terhadap caregiver atau keluarga pasien kanker anak untuk memfasilitasi praktik mindfulness bagi keluarga pasien.

\section{Kepustakaan}

Ali, K., Sutaryo, Purwanto I., Mulatsih, S., Supriyadi, E., Widjayanto, P. H., 
Sumadiono, \& Nurse, J. (2010). Yogyakarta pediatric cancer registry: An international collaborative project of University Gadjah Mada, University of Saskatchewan, and the Saskatchewan Cancer Agency. Asian Pacific Journal of Cancer Prevention, 11(1), 131-6. Diakses dari https://www.ncbi.nlm.nih.gov/pub med/20593943.

Asuero, A. M., Queralto, J. M., PujolRibera, E., Berenguera, A., Rodriguez-Blanco, T., \& Epstein, R. M. (2014). Effectiveness of a mindfulness education program in primary health care professionals: A pragmatic controlled trial. The Journal of Continuing Education in The Health Professions, 34(1), 4-12.

Baer, R. A., Smith, G. T., \& Allen, K. B. (2004). Assessment of mindfulness by self-report: The kentucky inventory of mindfulness skills. Assessment, 11(3), 191-206.

Bogels, S., \& Restifo, K. (2014). Mindful parenting: Guide for mental health practitioners. New York: Springer.

Brown, N. W., \& Ryan, R. M. (2003). The benefits of being present mindfulness and its role in psychological well-being. Journal of Personality and Social Psychology, 84(4), 822-448. doi: 10.1037/0022$\underline{3514.84 .4 .822}$

Carmody, J., \& Baer, R. A. (2009). How long does a mindfulness-based stress reduction program need to be? A brief review of class contact hours and effect sizes for psychological disorders. Journal of Clinical Psychology, 65, 627-638.
Carson, S. H., \& Langer, E. J. (2006). Mindfulness and self acceptance. Journal of Rational-Emotive $\mathcal{E}$ Cognitive Behaviour Therapy, 24(1), 29-43.

Chang, J. H., Huang, C. L., \& Lin, Y. C. (2015). Mindfulness, basic psychological needs fulfillment, and well-being. Journal of Happiness Studies, 16(5), 1-15. doi: 10.1007/s10902-014-9551-2

Compton, W. C., \& Hoffman, E. (2013). Positive psychology: The science of happiness and flourishing $2^{\text {nd }}$ ed. Belmont: Cengage Learning.

Creswell, J. D., Way, B. M., Eisenberger, N. I., \& Lieberman, M. D. (2007). Neural correlates of dispositional mindfulness during affect labeling. Psychosomatic Medicine, 69(6), 560565. doi: $\underline{\text { 10.1097/PSY.0b013e3180f61 }}$ $\underline{71 \mathrm{f}}$

Davis, D. M., \& Hayes, J. A. (2011). What are the benefits of mindfulness? A practice review of psychotherapyrelated research. Psychotherapy, 48(2), 198-208.

Dolgin, M. J., Phipps, S., Fairclough, D.L. (2007). Trajectories of adjustement in mothers of children with newly diagnosed cancer: A natural history investigation. Journal of Pediatric Psychology, 32(7), 771-782.

Ellis, P. D. (2010). The essential guides to effect size: Statistical power, metaanalysis, and the interpretation of research result. Cambridge: Cambridge University Press.

Fletcher, P. C. (2010). My child has cancer: The costs of mothers' experiences of having a child with pediatric cancer. Issues in Comprehensive Pediatric Nursing, 33(3), 164-84. 
Haines, J., Spadaro, K. C., Choi, J., Hoffman, L. A., \& Blazeck, A. M. (2014). Reducing stress and anxiety in caregivers of lung transplant patients: Benefits of mindfulness meditation. International Journal of Organ Transplantation Medicine, 5(2), 50-56.

Hölzel, B. K., Lazar, S. W., Gard, T., Schuman-Olivier, Z., Vago, D. R., \& Ott, U. (2011). How does mindfulness meditation work? Proposing mechanisms of action from a conceptual and neural perspective. Perspectives on Psychological Science, 6(6), 537-559.

Hoppes, S., Bryce, H., Hellman, C., \& Finlay, E. (2012). The effects of brief mindfulness training on caregivers' well-being. [Article]. Activities, Adaptation \& Aging, 36(2), 147-166.

Howarth, A., Perkins-Porras, L., Smith, J.G., Subramaniam, J., Copland, C., Hurley, M., Beith, I., Riaz, M., \& Ussher, M. (2016). Pilot study evaluating a brief mindfulness intervention for those with chronic pain: study protocol for a randomized controlled trial. BMC Psychology, 17(273), 1-12. doi: 10.1186/s13063-016-1405-2

Hanley, A., Warner, A., \& Garland. E.L. (2015). Associations between mindfulness, psychological wellbeing, and subjective well-being with respect to contemplative practice Journal of Happiness Studies: An Interdisciplinary Forum on Subjective Well-Being, 16(6), 14231436. doi: $\underline{10.1007 / \mathrm{s} 10902-014-9569-5}$

Kementerian Kesehatan Republik Indonesia. (2015). Infodatin: Pusat Data dan Informasi Kementrian
Kesehatan RI. Diunduh melalui www.depkes.go.id.

Keng, S. L., Smoski, M.J., \& Robins, C. J. (2011). Effects of mindfulness on psychological health: a review of empirical studies. Clinical Psychology Review, 31(6), 1041-56. doi: 10.1016/ j.cpr.2011.04.006.

Keyes, C. L. M., Shmotkin, D., Ryff, C. D. (2002). Optimizing well-being: The empirical encounter of two traditions. Journal of Personality and Social Psychology, 82(6), 1007-1022. doi : 10.1037/0022-3514.82.6.1007

Kohlsdorf, M., \& Costa-Junior, A. L. (2012). Psychosocial impact of pediatric cancer on parents: A literature review, Paidéia, 22(51), 119129.

Landis, J. R., \& Koch, G. G. (1977). The measurement of observer agreement for categorical data. Biometrics, 33(1), 159-174.

Lengacher C. A., Kip K. E., Barta, M., PostWhite, J., Jacobsen, P. B., Groer M., Lehman, B., Moscoso, M.S., Kadel, R., Le, N., Loftus, L., Stevens, C.A., Malafa, M. P., \& Shelton, M. M. (2012). A pilot study evaluating the effect of mindfulness-based stress reduction on psychological status, physical status, salivary cortisol, and interleukin- 6 among advanced-stage cancer patients and their caregivers. Journal of Holistic Nursing: Official Journal of the American Holistic Nurses' Association. 30, 170-85. doi: 10.1177/08980101114 $\underline{35949}$

Li, G., Yuan, H., \& Zhang, W. (2016). The effect of mindfulness-based stress reduction for family caregivers: 
Systematic review. Journal of Psychiatric Nursing, 30(2), 292-299.

Norberg, A. L., \& Boman, K. K. (2008). Parent distres in childhood cancer: A comparative evaluation of posttraumatic stress symptomps, depression, and anxiety. Acta Oncology, 47(2), 267-274.

Northouse, L. L., Katapodi, M. C., Schafenacker, A. M., \& Weiss, D. (2012). The impact of caregiving on the psychological wel-being of family caregivers and cancer pastients. Oncology Family Caregivers, 28(4), 236-245.

Okado, Y., Long, S., Phipps, S. (2014). Association between parent and child distress and the moderating effect of life events in families with and without a history of pediatric cancer. Journal of Pediatric Psychology, 39(9), 1049-1060.

Ryan, R. M., Deci., E. L. (2011). On happiness and human potentials: a review of research on hedonic and eudaimonic well-being. Annu Rev Psychol, 52(1), 41-66. doi: 10.1146/ annurev.psych.52.1.141.

Ryff, C. D. (1989). Happiness is everything, or is it? Explorations on the meaning of psychological well-being. Journal of Personality and Social Psychology, 57, 1069-1081.

Sani, F., \& Todman, J. (2006). Experimental design and statistics for psychology: A first course. Oxford: Blackwell Publishing Ltd

Segal, Z. V., Williams, J. M. G., \& Teasdale, J. D. (2002). Mindfulness-based cognitive therapy for depression: A new approach to preventing relapse. New York, NY: The Guilford Press.

Shadish, W. R., Cook, T. D., Campbell, D. T. (2002). Experimental and quasiexperimental designs for generalized causal. Houghton-Mifflin: Boston.

Stahl, B., \& Goldstein, E. (2010). A mindfulness-based stress reduction workbook (A new harbinger selfhelp workbook). New Harbinger Publications : California.

Vrijmoet-Wiersma, C. M., Van Klink, J. M., \& Kolk, A. M. (2008). Assesment of parental psychological stres in pediatric cancer: A review. Journal Pediatric of Psychology, 33(7), 694-706. Yayasan Onkologi Anak Indonesia. (2014). Diunduh melalui www.yoai foundation.org. 